\title{
The Subcutaneous Pedicle Tensor Fascia Lata Flap for Coverage of Trochanteric Pressure Sores: Surgical Technique
}

\author{
Torakanterik Bası Yaralarında Subkütan \\ Pediküllü Tensor Fasya Lata Flebi
}

\author{
Özlenen ÖZKAN, ${ }^{a}$ \\ Ömer ÖZKAN, ${ }^{a}$ \\ Anı CINPOLAT, \\ Gamze BEKTAŞ, \\ Tunç ŞAFAK
}

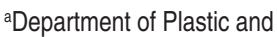

Reconstructive Surgery,

Akdeniz University Faculty of Medicine,

Antalya

${ }^{b}$ Department of Plastic and

Reconstructive Surgery,

Hacettepe University Faculty of Medicine, Ankara

Geliş Tarihi/Received: 08.08.2011

Kabul Tarihi/Accepted: 12.07.2012

The abstract of this article was presented in the $4^{\text {th }}$ National Microsurgery Congress 2009,

Antalya, $31^{\text {st }}$ National Plastic, Reconstructive and Esthetic Surgery Congress 2009, Adana, $6^{\text {th }}$ World Society of Reconstructive

Microsurgery Congress 2011, Helsinki.

Yazıșma Adresi/Correspondence: Özlenen ÖZKAN

Akdeniz University Faculty of Medicine, Department of Plastic and

Reconstructive Surgery, Antalya,

TÜRKIYE/TURKEY

ozlenend@yahoo.com

doi: 10.5336/medsci.2011-25896

Copyright $@ 2013$ by Türkiye Klinikleri

\begin{abstract}
The tensor fascia lata (TFL) flap is the method of choice for coverage of trochanteric pressure sores. Variations of this flap have been proposed to improve mobilization of the transferred tissue and reduce suture line tension, including dog-ears such as the V-Y advancement flap, the bilobed TFL flap and the duck modification, the hatched shaped TFL and subcutaneous TFL flaps. In this study, 19 subcutaneous pedicle TFL flaps with a minor modification were successfully used for the reconstruction of trochanteric pressure sores in fourteen patients. A subdermal tunnel was created instead of open incision between the recipient site and the donor site of the cutaneous part of the flap for preparation and rotation of the subcutaneous pedicle to reduce the risk of postoperative dehiscence problems and simultaneously provide a better cosmetic appearance. The results showed the reliability of the technique from both structural and aesthetic points of view.
\end{abstract}

Key Words: Pressure ulcer; subcutaneous tissue

ÖZET Torakanterik bası yaralarının kapatılmasında tensor fasya lata (TFL) flebi tercih edilen bir seçenektir. Transfer edilen dokunun mobilizasyonunu artırmak, dikiş hattında gerginliği azaltmak ve köpek kulaklarını gidermek için bu flebin varyasyonları geliştirilmiştir. V-Y ilerletme flebi, iki loblu TFL flebi ve subkütan pediküllü TFL flebi bunlardan bazılarıdır. Bu çalışmada, 14 hastanın torakanterik bası yarası rekonstrüksiyonunda 19 subkütan pediküllü TFL flebi modifiye değişiklikle başarılı bir şekilde uygulanmıştır. Alıcı ve donör alan arasında açık insizyon yerine subdermal bir tünel oluşturularak pedikülün bu tünelden geçirilmesi ve böylelikle ameliyattan sonra yara ayrılması problemlerinin azaltılmasının yanı sıra, iyi bir kozmetik sonuç elde edilmesi de sağlanmıştır. Sonuçlar hem yapısal hem de estetik açıdan tekniğin kullanılabilirliğini ve güvenilirliğini kanıtlar niteliktedir.

Anahtar Kelimeler: Bası ülser; cilt altı doku

Turkiye Klinikleri J Med Sci 2013;33(1):290-6

ince its introduction by Nahai et al. and Hill et al., the TFL flap has become the most popular reconstructive option for trochanteric ulcers, as well as for ischial, abdominal and inguinal urogenital region defects. ${ }^{1,2}$ The dominant pedicle is the transverse branch (ascending branch in some reports) of the lateral circumflex femoral artery and its vena comitantes. It has a flat shape, excellent length and reliable vascularity known in detail. Simple and quick planning and harvesting are the advantages of this flap. The TFL flap has been used frequently and successfully for trochanteric pressure sore coverage. 
Despite its well known advantages, however, it also has various disadvantages, such as donor site morbidity when the flap width is greater than 10 $\mathrm{cm}$, dog-ear deformity after flap transposition, the need to maintain the unnecessary proximal skin island elevation over the pedicle with the flap to preserve flap blood supply continuity, and the need to sacrifice a bridge of normal skin to inset the flap. Several modifications of the TFL flap have been developed to overcome the mentioned drawbacks. ${ }^{3-7}$ The subcutaneous pedicle flap not only overcomes these well known disadvantages of the classical TFL flap, but also has additional advantages mostly concerning the cosmetic appearance of both donor and reconstructed sites. In this report, we described our experiences with the use of the subcutaneous pedicled TFL flap for reconstruction of trochanteric pressure sore defects. The structural and aesthetic advantages of this modification were also described and were discussed.

\section{MATERIAL AND METHODS}

From November 2000 to March 2010, 19 subcutaneous pedicle TFL flaps were transferred for trochanteric defects in fourteen patients (Table 1). Defects were unilateral in nine patients and bilateral in the remaining cases. Four patients were female and ten male with an average age of 34 years (range; 19 to 65 years). Seven patients were paraplegic, three were quadriplegic and the remaining four patients were able to walk, their defects resulting from long-term hospitalization in the intensive care unit due to trauma and cerebrovascular injury. Ulcer size ranged from $3 \times 3 \mathrm{~cm}$ to $8 \times 12 \mathrm{~cm}$. Two patients had undergone prior operation with local flaps and the remaining twelve patients had not received surgical intervention. If the patient had a severe infection history, the initial treatment choice was antibiotic and local wound care. Complete blood count and total blood protein and albumin levels were recorded and normal values provided, in addition to the nutritional status of the patient.

\section{SURGICAL TECHNIQUE}

Surgery was performed under general anesthesia in four patients; no anesthesia was required in the remaining five. Patients were placed in the supine

\begin{tabular}{|c|c|c|c|c|c|c|c|c|c|}
\hline \multicolumn{10}{|c|}{ TABLE 1: Patient summary. } \\
\hline \multirow[b]{2}{*}{ Case No } & \multirow[b]{2}{*}{ Age } & \multirow[b]{2}{*}{ Sex } & \multirow[b]{2}{*}{ Site } & \multirow[b]{2}{*}{ Etiology } & \multirow[b]{2}{*}{ Ulcer size $(\mathrm{cm})$} & \multirow[b]{2}{*}{ Flap size $(\mathrm{cm})$} & \multicolumn{3}{|c|}{ Follow up period } \\
\hline & & & & & & & Able to walk & (months) & Complication \\
\hline 1 & 57 & $\mathrm{~F}$ & Right & Paraplegic, pressure sore & $7 \times 9$ & $7 \times 9$ & No & 44 & No \\
\hline 2 & 40 & M & Left & Paraplegic, pressure sore & $5 \times 6$ & $5 \times 7$ & No & 32 & Hematoma \\
\hline 3 & 65 & $\mathrm{~F}$ & Bilateral & Quadriplegic, pressure sore & $4 \times 5$ and $7 \times 12$ & $5 \times 5$ and $7 \times 13$ & No & 20 & No \\
\hline 4 & 23 & M & Right & $\begin{array}{l}\text { Complicated orthopeadic surgery, } \\
\text { pressure sore }\end{array}$ & $8 \times 12$ & $8 \times 13$ & Yes & 20 & $\begin{array}{l}\text { Dehiscense at the } \\
\text { donor site }\end{array}$ \\
\hline 5 & 40 & $\mathrm{~F}$ & Right & Quadriplegic, pressure sore & $7 \times 7$ & $7 \times 7$ & No & 20 & No \\
\hline 6 & 24 & M & Bilateral & Paraplegic, pressure sore & $4 \times 4$ and $4 \times 5$ & $4 \times 4$ and $5 \times 5$ & No & 18 & No \\
\hline 7 & 22 & M & Bilateral & Quadriplegic, pressure sore & $5 \times 5$ and $5 \times 6$ & $5 \times 5$ and $6 \times 6$ & No & 14 & No \\
\hline 8 & 37 & $\mathrm{~F}$ & Left & Paraplegic, pressure sore & $8 \times 8$ & $8 \times 8$ & No & 20 & Hematoma \\
\hline 9 & 48 & M & Left & Paraplegic, pressure sore & $7 \times 8$ & $7 \times 8$ & No & 20 & No \\
\hline 10 & 27 & M & Bilateral & Paraplegic, pressure sore & $3 \times 3$ & $3 \times 3$ & No & 14 & - No \\
\hline & & & & & $4 \times 5$ & $4 \times 5$ & & & \\
\hline 11 & 19 & M & Bilateral & Cerebrovascular injury, pressure sore & $4 \times 4$ and $7 \times 7$ & $4 \times 4$ and $7 \times 9$ & Yes & 11 & No \\
\hline 12 & 33 & M & Left & Cerebrovascular injury, pressure sore & $4 \times 4$ & $4 \times 6$ & Yes & 20 & No \\
\hline 13 & 22 & M & Right & $\begin{array}{l}\text { Complicated orthopeadic surgery, } \\
\text { pressure sore }\end{array}$ & $6 \times 6$ & $6 \times 7$ & Yes & 14 & No \\
\hline 14 & 20 & M & Right & Paraplegic, pressure sore & $8 \times 9$ & $9 \times 11$ & No & 14 & $\begin{array}{l}\text { Dehiscence at the } \\
\text { recipient site }\end{array}$ \\
\hline
\end{tabular}

F: female; M: male. 
position. Since trochanteric sores usually appeared with minimal skin involvement and extensive bursa formation together with a large undermined area under the skin, the ulcer with its surrounding fibrotic, necrotic and infectious tissues was completely debrided. The bony prominence of the trochanter was removed and efforts were made to smooth out any irregularities.

The anterior superior iliac crest, the lateral condyle of the femur and the lateral condyle of the tibia, the pubic tubercle, were marked. The transverse branch of the lateral femoral circumflex artery was located approximately 7 to $9 \mathrm{~cm}$ below the anterior superior iliac spine. The subcutaneous pedicle flap was then marked on the lateral surface of the thigh (Figure 1A). The anterior border of the flap was marked by a line connecting the anterior superior iliac spine to the lateral condyle of the tibia. The line placed on the greater trochanter of the femur and parallel to the first line (anterior border) was generally the posterior border.

The flap was designed to be approximately the same size as or a little larger (no more than $1 \mathrm{~cm}$ in width and length) than the defect area and with adequate distance to provide smooth rotation on the route of the pivot point, which did not allow kinking on the flap pedicle. When the borders of the skin incisions were marked, the incision proceeded obliquely in favor of the flap against the donor site to include more subcutaneous tissue with the flap to fill the dead undermined space in the defect. The flap was harvested with an incision starting from the inferior half of the anterior border, proceeding inferiorly and then turning around the complete inferior border of the flap to the inferior half of the posterior border. The inferior half of the flap was developed by incising deep to the fascia until the underlying muscle was exposed. At the superior border of the flap, an incision was made at the interface of the deep dermis and subcutaneous tissue (Figure 1B). A subcutaneous tunnel was created between this upper part of the flap and the defect, preserving subcutaneous tissue under this tunnel. A subcutaneous pedicle was placed on the route of the TFL, keeping the border marked preoperatively open between the anterior and posterior lines between the defect and the flap donor site. The anterior and posterior borders of the subcutaneous pedicle were incised down the deep muscle to the underlying muscle connecting the incision made in the inferior half. The flap was mobilized, releasing it from the deep surface over the muscle together with its subcutaneous pedicle. The flap was mobilized until it had enough mobil-
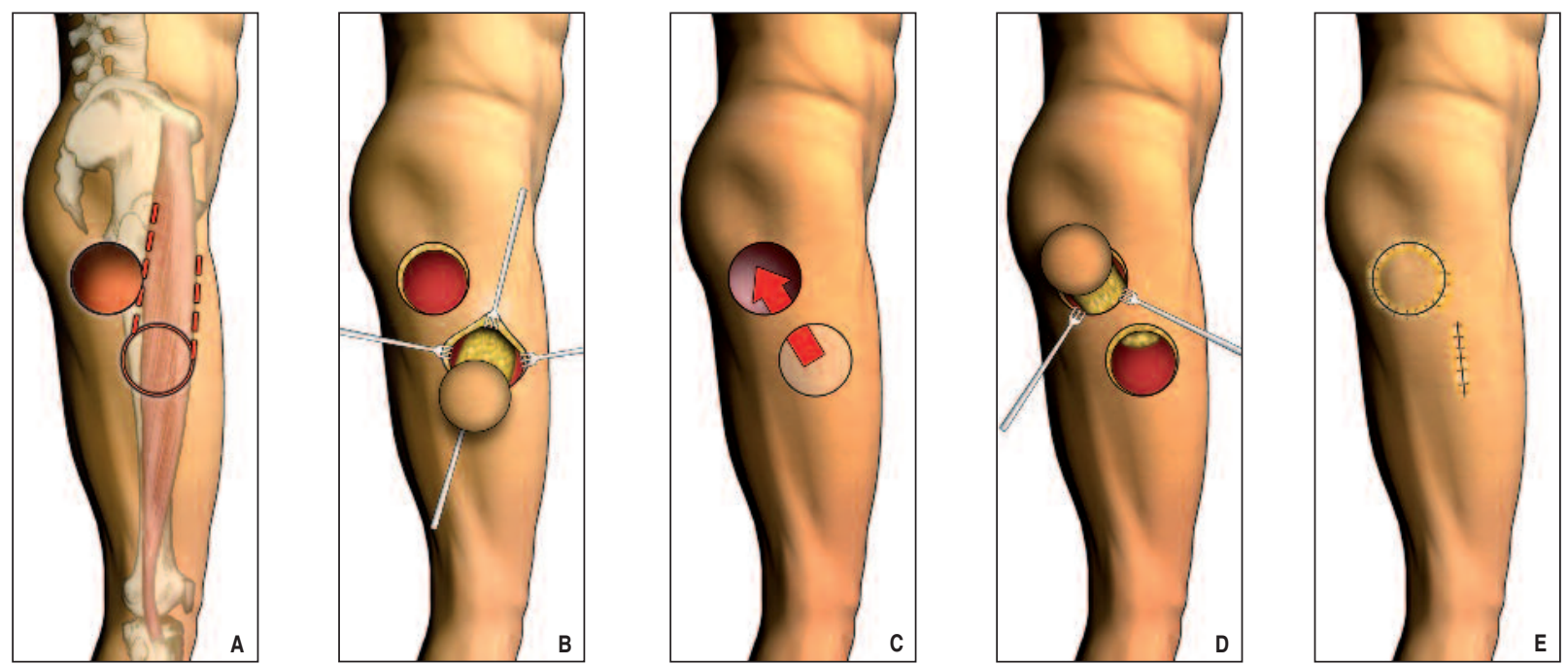

FIGURE 1: A) Defect and design of the subcutaneous pedicle tensor fascia lata flap. B) Elevation of the flap based on the subcutaneous pedicle with enough distance to provide smooth rotation in the route of the pivot point. C) Creation of the subcutaneous tunnel. D) Rotation of the flap to the recipient site. E) Flap inset and direct closure of the donor area.

(See for colored form http://tipbilimleri.turkiyeklinikleri.com/) 
ity to reach and cover the whole defect. The flap was then passed under the tunnel created based on its subcutaneous pedicle (Figure 1C and 1D). It was sutured in place to cover the whole defect without any tension (Figure 1E). Two hemovac suction drains were inserted, one under the flap, the other in the donor area. The donor site on the lateral thigh was closed primarily. Based on the design of the flap, during closure of the donor site, a small dog-ear correction was made when necessary.

\section{RESULTS}

The follow-up period varied between 3 and 36 months, with a mean duration of 13 months. The flap successfully covered all trochanteric sores. The mean duration of surgery for one flap was approximately 30 minutes. No remarkable blood loss was recorded. Patients were hospitalized for an average of 10 days (5 to 14 days). Suction drains were re- moved on approximately postoperative day 5 . No partial or total flap loss was observed. All donor sites closed directly without requiring skin grafting. Complications developed in four patients. Two patients developed hematoma under the hemovac drains due to the obstruction of the drain. The hematomas were drained by removing a few sutures, and the wounds healed without any additional intervention. Dehiscence of the incisions at the donor site in one patient and at the recipient site in another patient was observed; they healed secondarily.

Four ambulatory patients were able to walk with no flap-related functional impairment. During the follow up period, ulcers recurred in three patients, two being reconstructed unilaterally and the other bilaterally with a second recurrence being noted 6 months later in the unilateral patients and 3 months later in the bilaterally recon-
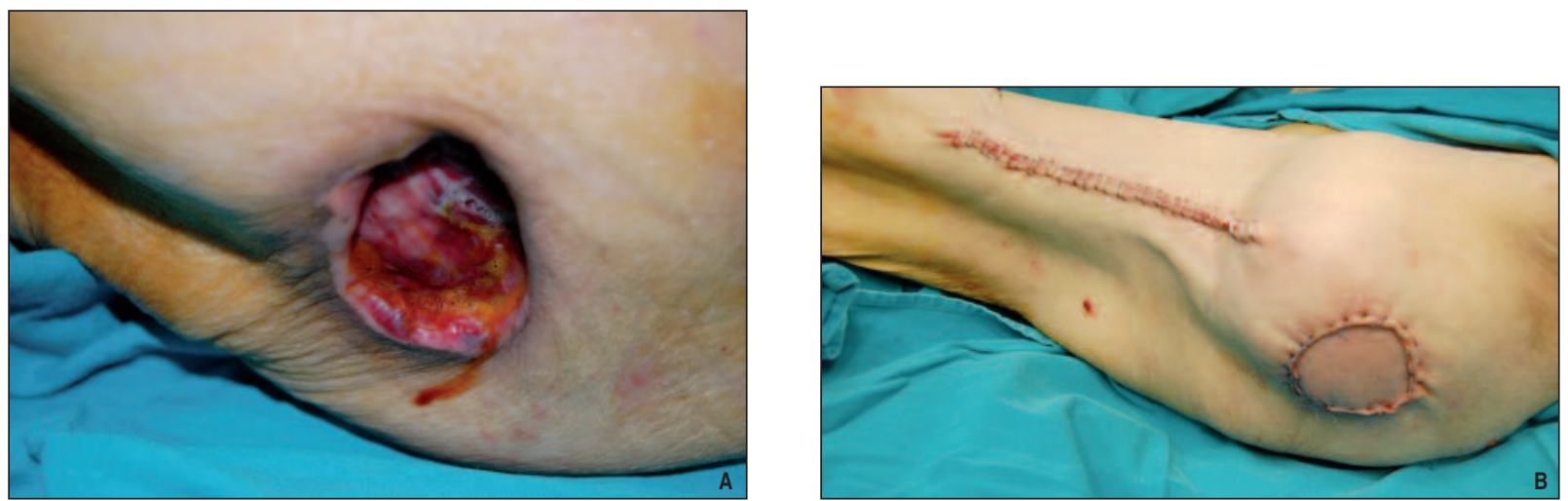

FIGURE 2: A) Preoperative view of a trochanteric pressure sore in a 24-year-old male patient. B) Immediate postoperative view of the transferred subcutaneous pedicle tensor fascia lata flap

(See for colored form http://tipbilimleri.turkiyeklinikleri.com/)
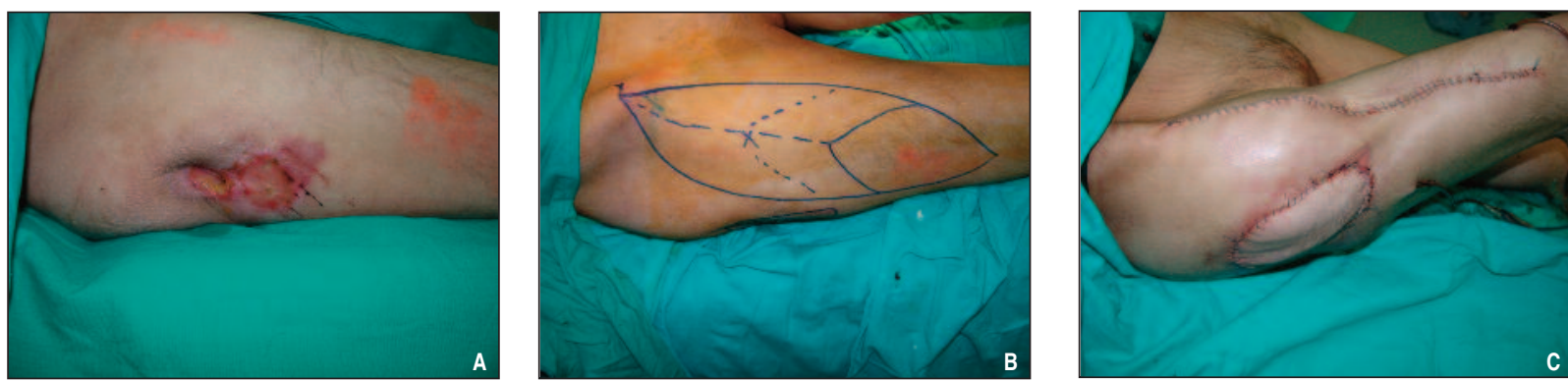

FIGURE 3: A) Preoperative view of a 37-year-old patient who had a trochanteric pressure sore with a small amount of skin defect compared with the large undermined pouch. B) Design of the subcutaneous pedicle tensor fascia lata flap. C) Immediate postoperative view of both the recipient and donor areas.

(See for colored form http://tipbilimleri.turkiyeklinikleri.com/) 

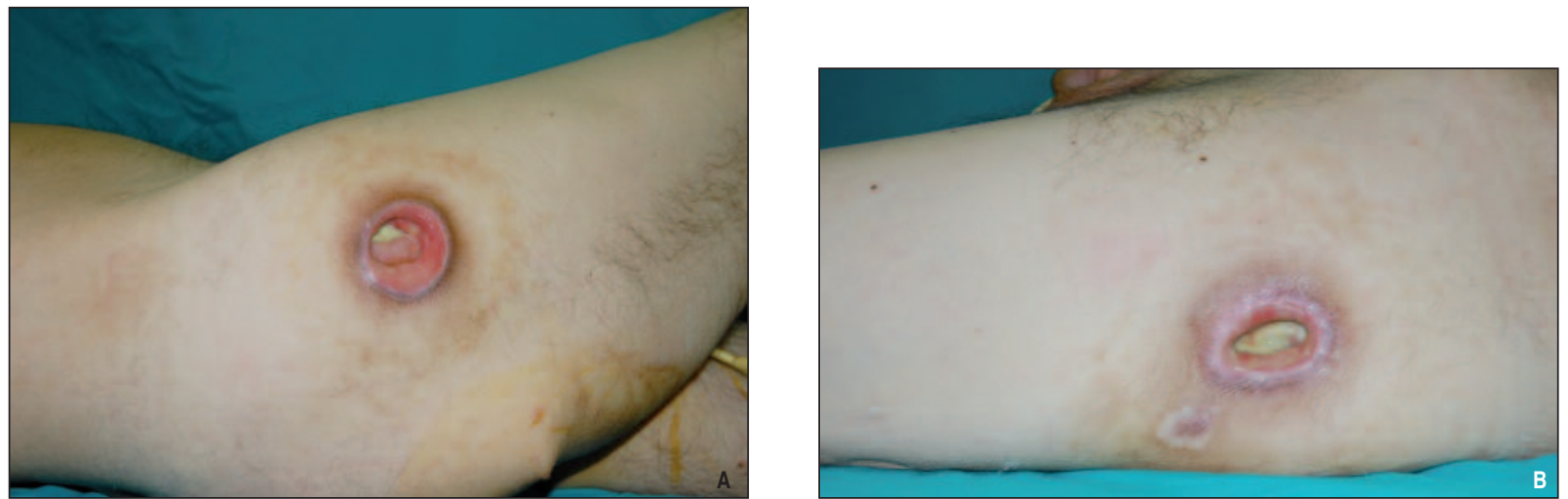

FIGURE 4A, B: Preoperative view of bilateral trochanteric pressure sore in a 27-year-old patient (A: right, B: left side).

(See for colored form http://tipbilimleri.turkiyeklinikleri.com/)
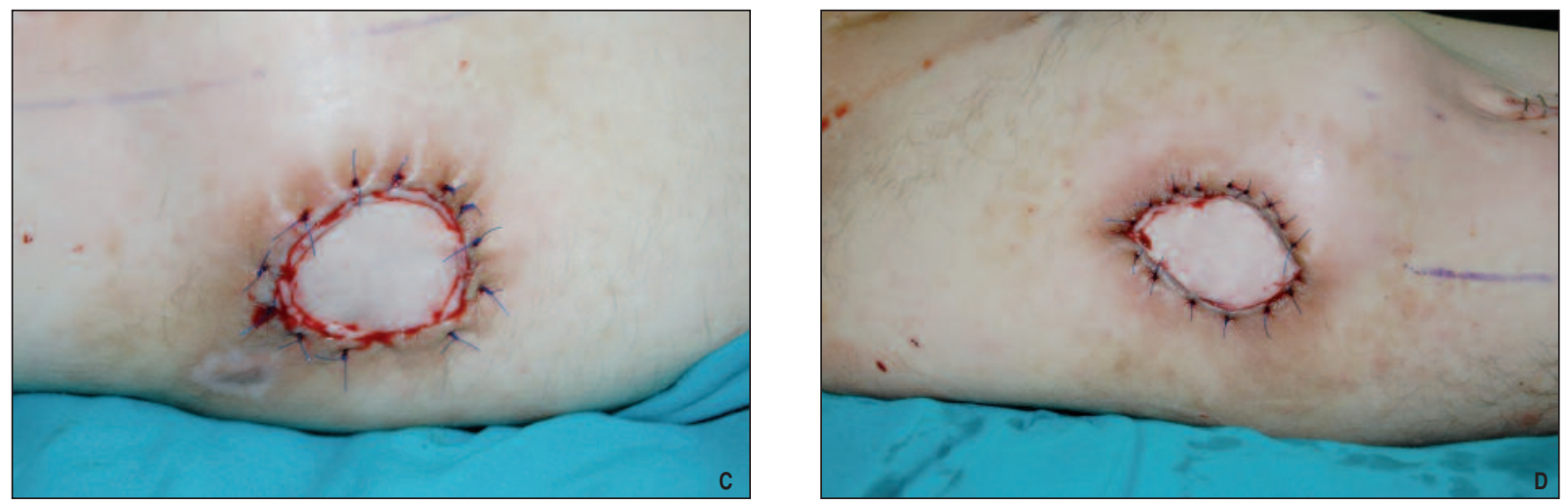

FIGURE 4C, D: Immediate postoperative view of the transferred flaps (C: right, D: left side).

(See for colored form http://tipbilimleri.turkiyeklinikleri.com/)
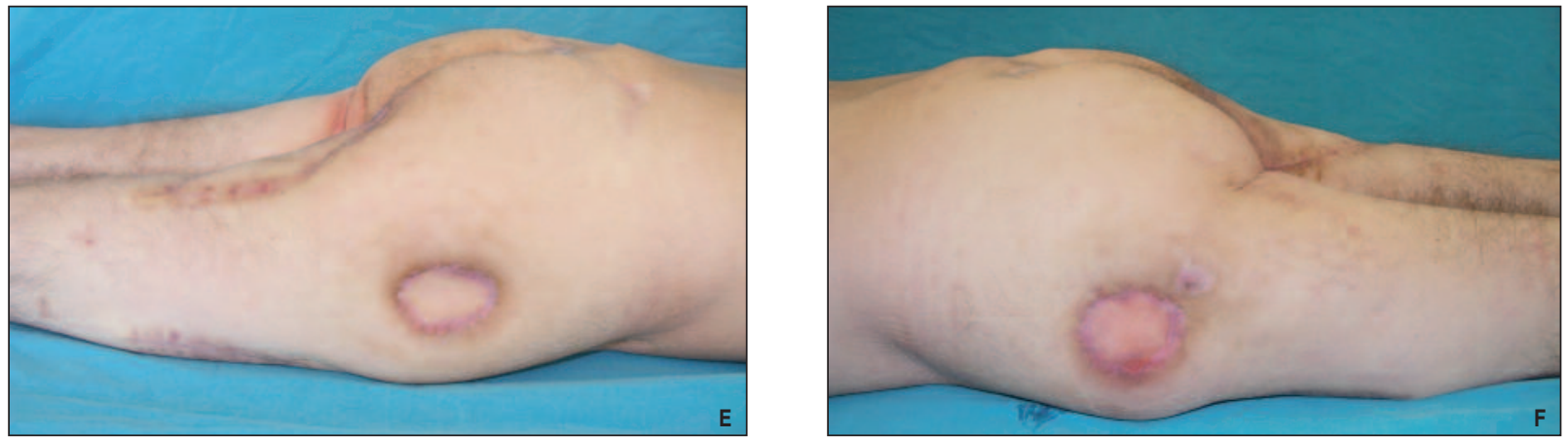

FIGURE 4E, F: Postoperative view 3 months after reconstructing the pressure sore defects with subcutaneous pedicle tensor fascia lata flaps (E: right, F: left side). (See for colored form http://tipbilimleri.turkiyeklinikleri.com/)

structed cases on both sides. All three cases were treated with a conservative regimen including local wound care. No surgical intervention was needed in either case. Representative patient examples were shown in Figures 2 through 5 (Figure $2,3,4,5,6)$.

\section{DISCUSSION}

Ischemic loss of tissue resulting from pressure over a bony prominence is the most important etiological factor for trochanteric defects in the form of sacral, ischial and heel defects. ${ }^{8,9}$ Defects mostly 


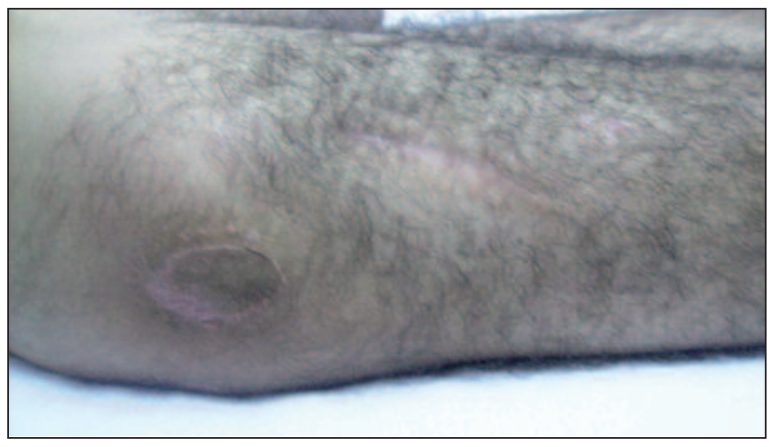

FIGURE 5: Postoperative view 20 months after reconstructing the pressure sore defects with subcutaneous pedicle tensor fascia lata flap. (See for colored form http://tipbilimleri.turkiyeklinikleri.com/)

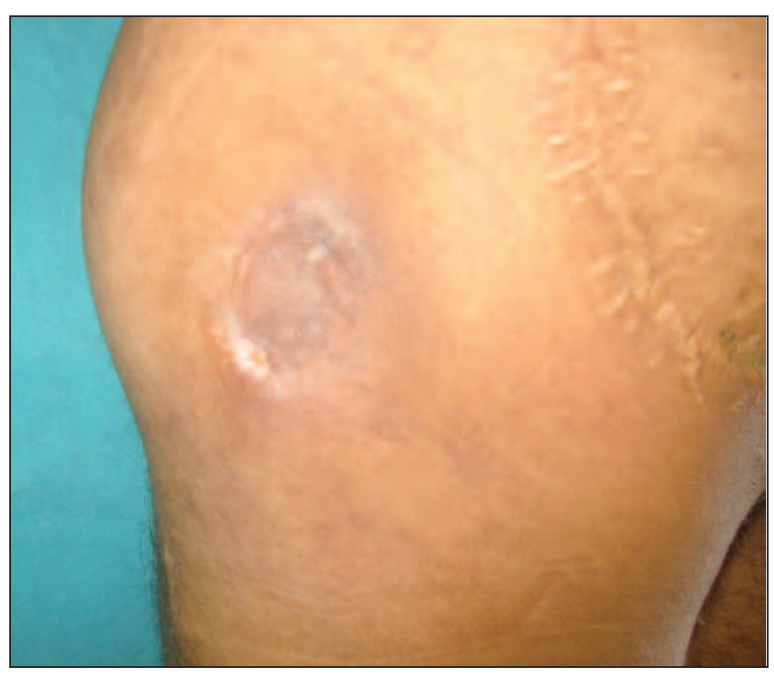

FIGURE 6: Postoperative wiev of 22 year-old man, 14 months after the subcutaneous pedicle tensor fascia lata flap reconstruction.

(See for colored form http://tipbilimleri.turkiyeklinikleri.com/)

occur after long-term immobilization, especially in unconscious individuals and in patients who are non-ambulatory due to paraplegia or quadriplegia. ${ }^{10,11}$ The mobile nature of the trochanter, particularly when spasm is poorly controlled, predisposes these ulcerations to extensive undermining. Since the pressure is transmitted from the surface to the underlying bone, gradually decreasing towards the periphery, while the defect is small, the undermining pouch is larger than the defect. The greatest extent of tissue ischemia and necrosis is therefore deep at the bony interface and less peripheral to this prominence, resulting in a small amount of skin defect compared with the under- mined pouch. ${ }^{12}$ Pressure sores thus characteristically begin deep, with their tips at the skin surface. The defect is usually conical in shape, like an iceberg. Obliteration of undermined dead space is as important as coverage of the skin defect. ${ }^{13}$

There are a few flap options for trochanteric pressure sores, mostly located on the thigh. The TFL flap has become the flap of choice for coverage since its introduction by Nahai et al. and Hill et al. ${ }^{1,2}$ It has usually been used as a posterior transposition flap. The distal part of the posterior transposition flap is not always reliable, however. Use of this flap in this standard way always causes a dog-ear deformity. Between the rotation point of the flap and the donor area there is a T-junction that is usually closed under tension, which often separates and causes dehiscence post-surgery. ${ }^{14}$

Some modifications have been developed to overcome the disadvantages of the posterior transposition flap, such as V-Y advancement, the 'duck' modification of the TFL flap, the hatchet-shaped TFL musculocutaneous flap, the bilobed TFL musculocutaneous flap and the TFL perforator flap. ${ }^{3-7}$

The subcutaneous pedicle flap was first described by Şafak et al. in 1996. ${ }^{14}$ In that study, the subcutaneous pedicled flap was employed to cover ischial, trochanteric pressure sores, to reconstruct the lower abdominal wall and for penile reconstruction. In their study, they mostly used inverted $\mathrm{T}$ incision for discovering the flap pedicle. We did not use the $\mathrm{T}$ incision. Instead, we prepared and isolated the subcutaneous pedicle under a subdermal tunnel. Thus, with any incision between the recipient site and donor area, there would be no risk of dehiscence compared with the presence of a $\mathrm{T}$ incision close to the defect, which is at high risk due to high tension over this point.

The subcutaneous pedicle TFL flap is safe, practical, requires only a short operation time and results in a short donor site incision. The flap is designed like the defect area, and minimal scar revision is necessary to protect the donor site from dog-ear deformity. Since the trochanteric defect generally resembles an iceberg, the defect is filled 
in by the bulk of the pedicle of the flap. It is especially important to fill dead space with a viable tissue. Additionally, by putting this bulk into the undermined space there will be no swelling and the reconstruction will result in a smooth surface. Obtaining a small improvement in shape will enhance motivation and increase emotional status in a positive way in patients, most of whom harbor negative feelings.

In conclusion, the subcutaneous TFL flap solves almost all the problems of the classic posterior transposition flap and has all the advantages of the other modifications. Considering the TFL flap the most valuable option for trochanteric pressure sores, we believe that as experience is acquired with the technique the subcutaneous TFL flap will be one of the most useful modifications thereof for the repair of trochanteric pressure sores from both the structural and cosmetic points of view.

\section{Acknowledgment}

This experimental study was supported by the Akdeniz University Scientific Research Projects Unit. We thank them for their support for this study.

\section{REFERENCES}

1. Nahai F, Silverton JS, Hill HL, Vasconez LO. The tensor fascia lata musculocutaneous flap. Ann Plast Surg 1978;1(4):372-9.

2. Hill HL, Nahai F, Vasconez LO. The tensor fascia lata myocutaneous free flap. Plast Reconstr Surg 1978;61(4):517-22.

3. Lynch SM. The bilobed tensor fascia lata myocutaneous flap. Plast Reconstr Surg 1981; 67(6):796-8

4. Erçöçen AR, Apaydin I, Emiroğlu M, Yilmaz S, Adanali G, Tekdemir I, et al. Island V-Y tensor fasciae latae fasciocutaneous flap for coverage of trochanteric pressure sores. Plast Reconstr Surg 1998;102(5):1524-31.

5. Demirseren ME, Gökrem S, Ozdemir OM, Katircioğlu A, Can Z, Serel S. Hatchet-shaped tensor fascia lata musculocutaneous flap for the coverage of trochanteric pressure sores: a new modification. Ann Plast Surg 2003; 51(4):419-22.
6. Ishida LH, Munhoz AM, Montag E, Alves HR, Saito FL, Nakamoto HA, et al. Tensor fasciae latae perforator flap: minimizing donor-site morbidity in the treatment of trochanteric pressure sores. Plast Reconstr Surg 2005;116(5): 1346-52.

7. Aslan G, Tuncali D, Bingul F, Ates L, Yavuz $N$. The "duck" modification of the tensor fascia lata flap. Ann Plast Surg 2005;54(6):637-9.

8. Phillips LG, Robson MC. Pressure ulcerations. In: Jurkiewicz MJ, Mathes SJ, Krizek TJ, Ariyan S, eds. Plastic Surgery. Principles and Practice. Vol 2. 1st ed. St. Louis: Mosby; 1990. p.1223-51.

9. Tunçbilek G, Nasir S, Ozkan O, Kayikçioğlu A, Mavili E. Partially de-epithelialised and buried V-Y advancement flap for reconstruction of sacrococcygeal and ischial defects. Scand J Plast Reconstr Surg Hand Surg 2004;38(2):94-9.
10. Ortak T, Özdemir R, Taner ÖF, Ünlü RE, Sensoz Ö. [Etiologic and surgical evaluation of 476 patients with pressure sores]. Turkiye Klinikleri J Med Sci 2003;23(1): 18-22.

11. Balık $O$, Reşat AA, Menderes A. [Eccentric located pressure sores and minor medical interventions: letter to editor]. Turkiye Klinikleri J Med Sci 2008;28(6):1008-10.

12. Erhan B. [Classification and evaluation of pressure sore]. Turkiye Klinikleri J Int Med Sci 2007;3(45):21-4.

13. Yılmaz M, Vayvada H, Karaca C. [Surgical treatment of pressure sores]. Turkiye Klinikleri J Int Med Sci 2007;3(45):45-56.

14. Safak T, Klebuc MJ, Keçik A, Shenaq SM. The subcutaneous pedicle tensor fascia lata flap. Plast Reconstr Surg 1996;97(4): 765-74. 